DOI: $10.4274 /$ tod. 60490

Turk J Osteoporos 2017;23:107-9

\title{
Incidentally Diagnosed Osteopoikilosis: A Case Report
}

\author{
Tesadüfen Saptanan Osteopoikiloz: Olgu Sunumu \\ Mustafa Reşorlu, Ozan Karatağ, Canan Akgün Toprak, Davut Döner* \\ Çanakkale Onsekiz Mart University Faculty of Medicine, Department of Radiology, Çanakkale, Turkey \\ *Çanakkale Onsekiz Mart University Faculty of Medicine, Department of Physical Medicine and Rehabilitation, Çanakkale, Turkey
}

\section{Abstract}

Osteopoikilosis is a rare bone dysplasia. Patients are generally asymptomatic and are frequently identified during radiological imaging by coincidence. The epiphysis and metaphysis of the long bones, the phalanges and pelvic bones are the localizations which frequently involved. It appears as oval or round, homogeneous, symmetrical, uniform, radio-opacities. Osteoblastic metastases, mastocytosis, tuberous sclerosis and Paget's disease should be considered in differential diagnosis.

Keywords: Osteopoikilosis, metastases, bone dysplasia

\section{Öz}

Osteopoikiloz nadir görülen bir kemik displazisidir. Hastalar genelde asemptomatiktir ve sıklıkla radyolojik görüntüleme sırasında tesadüfen saptanmaktadır. Uzun kemiklerin epifiz ve metafizleri, falankslar, pelvik kemikler sık tutulan lokalizasyonlardır. Oval ya da yuvarlak, homojen, simetrik, uniform, radyoopasiteler şeklinde görülürler. Ayırıı tanıda osteoblastik metastazlar, mastositoz, tüberoskleroz, Paget hastalığı akılda tutulmalıdır.

Anahtar kelimeler: Osteopoikiloz, metastaz, kemik displazisi

\section{Introduction}

Osteopoikilosis, also known as osteopathia condensans disseminata, is a rare bone dysplasia of uncertain etiology and pathogenesis (1). Hereditary or sporadic cases have been reported, and the genetic transmission has been shown to be autosomal dominant (2). It occurs as a result of abnormality in the bone maturation process. The condition is seen at similar levels in both sexes, with an estimated incidence of 1/50.000 (3). Patients are generally asymptomatic and are identified incidentally during radiological examinations performed for different causes (4). Numerous well-defined sclerotic lesions are observed at radiological examination. Sclerotic bone lesions, particularly bone metastasis must be thought in differential diagnosis (5). In this report we describe a case incidentally identified as osteopoikilosis at computerized tomography (CT) performed due to trauma.

\section{Case Report}

A 19-year-old male patient with a history of trauma four days previously presented to the emergency department with headache and tenderness in the lower abdomen and right thigh. He had no history of chronic disease. Apart from alanine aminotransferase elevation (52.9 U/L), no pathology was determined at routine laboratory tests. No findings were present except for swelling and tenderness in the soft tissue of the right thigh at physical examination. Cranial and thoracoabdominal CT were performed due to post-traumatic headache and abdominal tenderness. Non-displaced fracture was detected on the left side of the occipital bone. Abdominal $\mathrm{CT}$ and pelvis radiography revealed numerous uniform, homogeneous, millimetric and symmetrically distributed hyperdense nodular lesions in the sacrum, acetabulum and bilateral femoral epiphysis and metaphysis in this patient with no identified emergency pathology (Figures 1, 2). Radiological imaging of the lung, hip and hands in the radiology archive, performed two years previously, were re-evaluated. Similar radiological foci were present in the metacarpal heads. When the pulmonary X-ray and current thoracic CT were evaluated together, the opacities in the humeral heads were stable. Osteopoikilosis was diagnosed on the basis of typical radiological findings in the absence of any pathology in the physical examination and laboratory results. The joints were evaluated as normal at physical examination, and no

Address for Correspondence/Yazıșma Adresi: Mustafa Reşorlu MD, Çanakkale Onsekiz Mart University Faculty of Medicine, Department of Radiology, Çanakkale, Turkey Phone: +90 5054548722 E-mail: mustafaresorlu77@gmail.com ORCID ID: orcid.org/0000-0002-2941-8879

Received/Geliş Tarihi: 21.12.2016 Accepted/Kabul Tarihi: 12.10.2017

${ }^{\circ}$ Copyright 2017 by the Turkish Osteoporosis Society

Turkish Journal Of Osteoporosis published by Galenos Yayınevi. 
radiological pathology was observed in the shoulder or hip joints entering the imaging field. No pathological finding was determined at inspection and skin examination. The patient was followed-up for head trauma and discharged in a healthy condition

\section{Discussion}

Osteopoikilosis is a bone dysplasia that can be seen at any age and with a similar incidence in the two sexes. Genetic transmission is thought to be autosomal dominant,
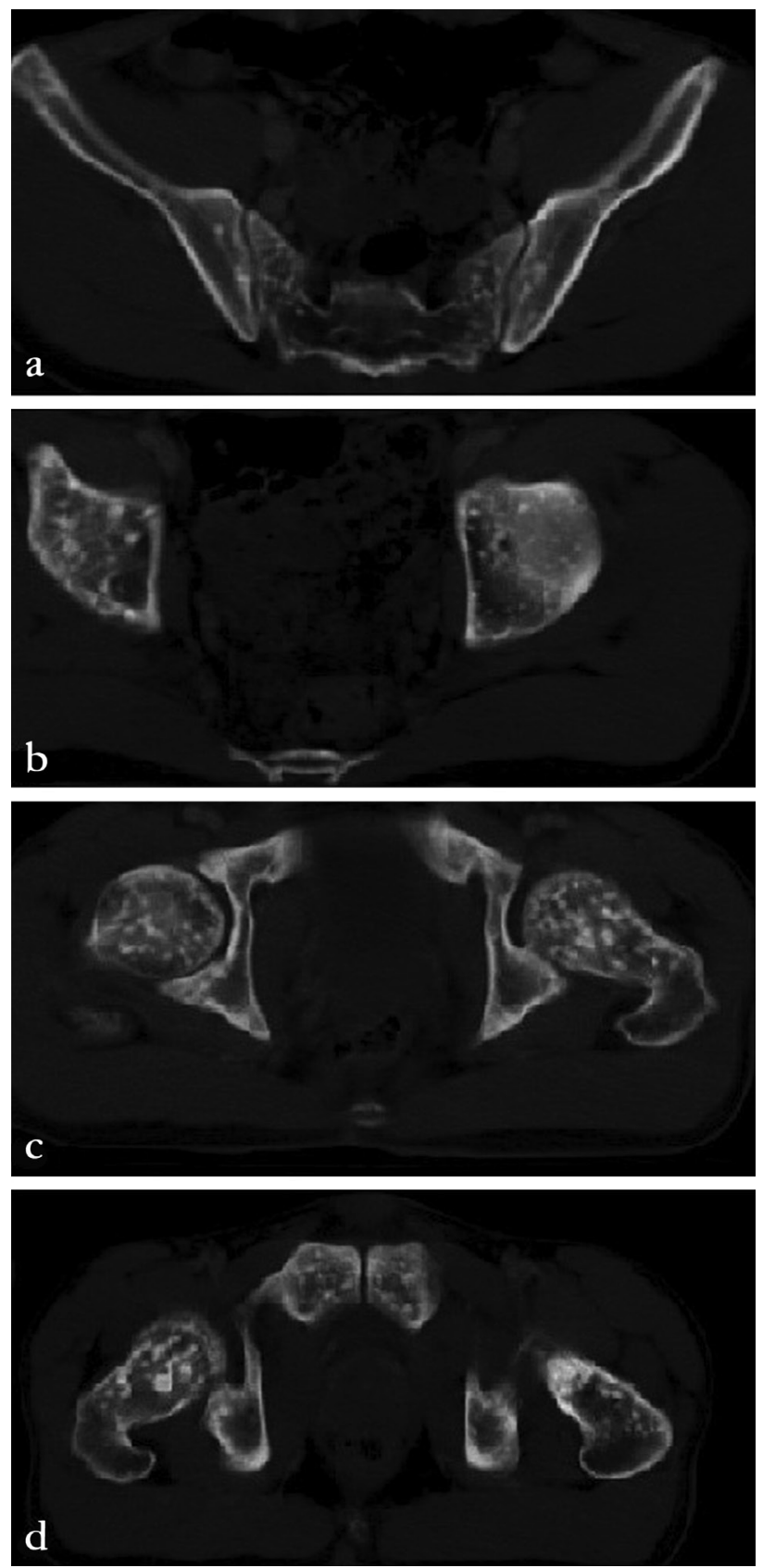

Figure 1. Millimetric, hyperdense sclerotic foci in the sacrum, acetabulum and neck of the femur on axial computerized tomography sections and mutations in the LEMD3 gene have been implicated $(2,6)$. Publications in the literature have reported that osteopoikilosis is associated with dacryocystitis, keloid, syndactyly, scleroderma, endocrine and metabolic diseases and cardiac anomalies $(6,7)$. Comorbid connective tissue lesions known as dermatofibrosis lenticularis have been reported on the skin in some cases. This combination is known as Buschke-Ollendorff syndrome (8). We determined no dermatological pathology during systemic examination in our case. While patients with osteopoikilosis are generally asymptomatic, cases with effusion in the joint spaces and joint pain have been reported. Joint symptoms affect approximately $20 \%$ of this patient group (9). Joint pain can be incidental in osteopoikilosis, or increased bone metabolism in this location or irritation of the joint capsule in association with venous stasis may be involved (9). There was no joint dysfunction or joint pain in our case, and those joints included the imaging field were radiologically normal. Typical radiological findings are round or oval, homogeneous, symmetrical, uniform radio-opacities 2-10 $\mathrm{mm}$ in diameter. Typically affected locations include the epiphysis and metaphysis of the long bones, the phalanges, the pelvic bones and the carpal and tarsal bones (5). Osteoblastic metastases in particular must be excluded at differential diagnosis. Metastasis must be considered in the presence of primary malignity, bone destruction, periosteal reaction, axial skeleton involvement or impaired uniformity. Rare involvement of the vertebra, costa and cranium in osteopoikilosis, and normal bone scintigraphy is important in differentiating from metastasis. Normal laboratory findings and typical morphological features of opacities can assist in differentiating from mastocytosis, tuberous sclerosis and Paget's disease $(4,7)$. In conclusion, osteopoikilosis is a frequently asymptomatic benign bone dysplasia. Its clinical significance is that it can be differentiated from other pathologies proceeding with sclerosis. While pain is rare, when symptomatic cases, analgesics such as acetaminophen and non-steroid anti-inflammatories can be used in treatment (10).

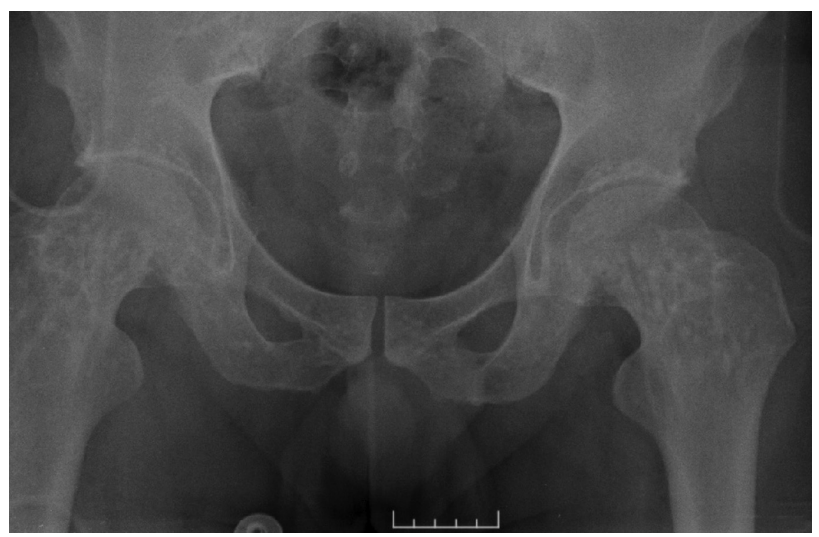

Figure 2. Radiopaque foci compatible with osteopoikilosis on radiography image 


\section{Ethics}

Informed Consent: It was taken.

Peer-review: Externally and internally peer-reviewed.

\section{Authorship Contributions}

Surgical and Medical Practices: D.D., Concept: M.R., O.K., Design: M.R., O.K., C.A.T., Data Collection or Processing: M.R., O.K., D.D., Analysis or Interpretation: C.A.T., D.D., Literature Search: M.R., O.K., C.A.T., D.D., Writing: M.R., O.K., C.A.T., D.D.

Conflict of Interest: No conflict of interest was declared by the authors.

Financial Disclosure: The authors declared that this study received no financial support.

\section{References}

1. Burnaz Ö, Çetin E, Özgönenel L, Örnek GT, Çağlar NS. Osteopoikiloz: Olgu Sunusu. İstanbul Tıp Dergisi 2008:3;150-2.

2. Sarralde A, Garcia-Cruz D, Nazara Z, Sanchez-Corona J Osteopoikilosis: report of a familial case. Genet Couns 1994;5:373-5.
3. Carpintero P, Abad JA, Serrano P, Serrano JA, Rodriguez P, Castro L. Clinical features of ten cases of osteopoikilosis. Clin Rheumatol 2004;23:505-8.

4. Du Mortier A, Docquier PL. Traumatic fracture in a patient with osteopoikilosis. Case Rep Orthop 2014;2014:520651.

5. Yu WJ, Fang TS, Cheng LG. [Imaging diagnosis of osteopoiknosis: a report of 6 cases in four generations of one family and 3 sporadic cases]. Zhongguo Gu Shang 2016;29:566-9.

6. Özkan FÜ, Soyluboy FN, Taraktaş A, Akpınar P, Külcü DG, Anıl $B$, et al. Osteopoikilozis: Olgu sunumu. Göztepe Tıp Dergisi 2014;29:146-8.

7. Ozdemirel $A E$, Cakit BD, Erdem HR, Koc B. A rare benign disorder mimicking metastasis on radiographic examination: a case report of osteopoikilosis. Rheumatol Int 2011;31:1113-6.

8. Hellemans J, Preobrazhenska O, Willaert A, Debeer P, Verdonk PC, Costa T, et al. Loss-of-function mutations in LEMD3 result in osteopoikilosis, Buschke-Ollendorff syndrome and melorheostosis. Nat Genet 2004;36:1213-8.

9. Mahbouba J, Mondher G, Amira M, Walid M, Naceur B. Osteopoikilosis: A rare cause of bone pain. Caspian J Intern Med 2015;6:177-9.

10. Woyciechowsky TG, Monticielo MR, Keiserman B, Monticielo OA. Osteopoikilosis: what does the rheumatologist must know about it? Clin Rheumatol 2012:31:745-8. 